\title{
Renewal of Jewish Life in Germany: From Guilt to Responsibility
}

\author{
Rabbi Harvey Meirovich \\ HMeirovich@beth-tzedec.org \\ School of Jewish Theology, Potsdam University's \\ the Geiger-Frankel Rabbinical College in Berlin
}

\section{Resumen}

El artículo, de género testimonial, se refiere al renacimiento de la vida judía en Alemania, las relaciones entre judíos y no judíos en dicho país, y el renacimiento de la enseñanza de la cultura judía a nivel universitario.

Palabras claves: Judíos en Alemania - Estudios judaicos - Resiliencia - Postdam - Teología judía.

\begin{abstract}
The article belongs to the testimonial genre and refers to the rebirth of Jewish life in Germany, the relations between Jews and non-Jews in that country and the revival of Jewish culture teaching at university level.
\end{abstract}

Key words: Jews in Germany - Jewish studies - Resilience - Postdam - Jewish theology. 
Hope and resilience are two qualities that spell out the will to survive of the Jewish people. Hope and resilience are integral components of the DNA that define the Jewish spirit. The embodiment of these two virtues in the Jewish psyche explain why, time and again, wherever Jews have settled, optimism eventually trumps pessimism. No one has to tell the Jewish people that to feel and fail, to stumble and sin, to rise and fall, are endemic features of being human. But, rather than wallow in self-pity, or drink ourselves into a stupor in front of the TV, or look for escape routes in the ashrams of Tibet and Nepal, the DNA of Jewish culture has always held a seat of honor for hope and resilience; taken together they keep our focus on what might yet be possible.

This lesson has come alive for me through my fortunate appointment as a visiting professor at the School of Jewish Theology at Potsdam University, a suburb of Berlin, and at the combined Abraham Geiger (Reform) and Zecharias Frankel (Masorti/Conservative) rabbinical schools in Berlin proper.

My wife, Cheryl, and myself find ourselves in the company of a cluster of committed Jews who belong to the liberal wing of the Berlin Jewish community. It is a privilege to encounter them close-up as they struggle to renew Jewish life, in of all places, Germany. Our experiences testify to how pessimism and despair are ultimately no match when confronted with the positive forces of hope and resilience.

I am particularly privileged to interact with undergraduate and graduate students at Potsdam University, most of whom are in their early to mid-twenties, and include a mix of Jews and Gentiles. Deep down I sense that most of my teaching goes well beyond cramming their heads with information; it has more to do with explaining and unravelling the mysteries of Jewish survival and creativity. My students are curious, some to the point of obsession with wanting to know what makes the Jewish people 'tick,' and how Judaism as a way of thinking and behaving join together as a full-bodied life-equation.

Many of my Jewish students were born into highly assimilated homes; others are Jews bychoice, having only recently shed their Gentile identities. What they hold in common is the 
absence of Jewish memories; both groups sit before me, by and large as clean slates, waiting for me to engrave my thoughts on their minds; a task that is sacred as it is daunting.

I am equally intrigued by my non-Jewish students. After all, with a Jewish population hovering around 200,000, including many non-halakhic Jews from the FSU, it is fair to say that most Germans have never met a Jew! My Gentile pupils are genuinely determined to learn the Hebrew language; many of them have spent significant time in Israel.

What propels their curiosity? Honestly, I don't yet have complete answers. I only have stories I am trying to make sense of. One bright young woman, Victoria, hails from a long-line of Lutheran ministers. On a recent train ride back to Berlin, she suddenly belts out she is seriously thinking about converting to Judaism. I ask myself: What did she know of Jews and Judaism before entering my class? Did she hear things negative, things positive as part of her own family tradition? Is this what is propelling her? One thing is clear: she is searching for her own answers.

I am thunder-struck by my students' intellectual lust; by their passion, as Jews, to discover their Jewish roots; and, as Gentiles, by their determination to put together some of the pieces of the puzzle that will make Judaism less mystifying. I don't know if it is my projection, or actually tapping into my students' minds: I have a sensation that so much of my class performance is linked to peeling away a mysterious aura that surrounds Judaism and the Jewish people. I say this because it was the puzzling and baffling nature of Judaism and the Jews that enabled a mad man, two generations ago, to convince an entire nation that mystery and the devil were embodied in the Jewish soul!

Hope and resilience are also featured in the congregational life of the Masorti/Conservative community that has its home at the historic landmark synagogue, Oranienbergerstrasse New Synagogue in Berlin. Built in the mid-19th century, the synagogue was destroyed by Allied bombing towards the end of WWII. In its heyday it was cavernous with a seating capacity of 3500 worshippers. Today, what remains of the actual synagogue is considerably more modest in size, with an impressive museum, and an actual synagogue sanctuary with seating for around 150 people. 
Compare these numbers of the past against the present and we could quite naturally offer up a lament: Oh, how the mighty have fallen! But, instead, the Masorti Jewish community has adopted the motto of hope and resilience. It does so against a positive political and sociological backdrop. Indeed, German Jewry has two positives going for it: notwithstanding its share of antiSemitic and anti-Zionist voices, it is indisputably the safest place for Jews to live in Europe; and it has the economic and legislative muscle of the German government, vigorously supporting the renewal of Jewish life.

To fathom the prospects for Jewish renewal requires tapping into some general German statistics: Germany is the second most popular migration destination in the world, after the United States. Is it any wonder that 20,000 Israelis have chosen to settle permanently in Germany. Berlin, in particular, displays a cosmopolitan face; in a city-wide population of 3.5 million there are more than 190 foreign nationalities, flourishing side by side. To see first-hand on the train to Potsdam the mix of students from diverse ethnic nationalities is to know deep down how far Germany's democratic pendulum has swung from its Nazi years of terror, and its rejection of the Jew as outsider.

This year marks a half century of full diplomatic relations between Germany and Israel. How many Jews are aware that Germany's democratic system is so vibrant and sophisticated that Israel's Supreme Court justices often refer to Germany's legal code as a source of inspiration for decisions that emanate from Jerusalem?

A trip to Germany's parliamentary building, the Reichstag, in the heart of Berlin, offers a profound glimpse into the meaning of democratic openness: completed in 1999, the Reichstag's dome is fashioned from glass. Standing at the top one can look below through 360 mirrors that reflect light downward directly into the chambers of the German parliament. The transparency is intentional; unlike the Nazi era, the dome symbolizes that the people are above the government while the transparency captures democracy at work.

When German Chancellor Angela Merkel stands at the Brandenburg Gate, in the center of Berlin, and in Israel's Knesset, and says that Germany's Jews are a national treasure, she 
expresses more than a political nicety. Her declaration comes from the heart. When she says in the name of all Germans that Israel's security is not negotiable, we are eons away from the 1930s.

Fact: Israel's navy currently has several Dolphin-class submarines built in Germany, very likely built with nuclear capability. All of these subs have been fully or partially funded with German money to the tune of hundreds of millions of dollars. According to the newspaper "Der Spiegel", these subs can carry a warhead of up to 200 kilograms. The actual nuclear warheads are produced, it is presumed, at Israel's Dimona nuclear reactor.

Although Chancellor Merkel has denied that the submarines have the capability to carry nuclear warheads, according to the Spiegel report, the German government has long been aware of the nuclear capability of the submarines; but out of understanding for Israel's security needs, has always agreed to "look the other way." So, when Angela Merkel locks horns with PM Netanyahu over how best to broker a deal with the Palestinians, her disagreement hardly makes her an antiSemite; after all some $40 \%$ of Israel's own citizens agree with her political stance.

Unlike France, at least up until recently, Germany has programs in place aimed at economic integration of its immigrant population. Educationally, German children are taught to respect diversity of cultures and religion; these lessons go hand-in-hand, year after year, of learning about the horrors of the Nazi era.

Last summer on a blistering hot day Cheryl and I walked around the Sachsenhausen concentration camp, a half hour train drive north of Berlin. Along with us were several clusters of German teenagers learning first-hand about one of Germany's first concentration camps, opened in 1936.

We entered one of the original barracks. The heat wave was so intense and stifling inside we could not wait to exit. Meanwhile, a group of some fifteen teenagers were detained as their chaperon slowly delivered an extended monologue; no doubt his words held less value than his exposing his charges to a smidgeon of the dehumanization felt by the 200,000 prisoners who passed through the gates of the camp. 
Urban legend has it that during the heyday of Russian Jewish emigration from the Former Soviet Union in the early 1990s, certain government circles in Israel insisted that Germany close its borders to the tidal wave of Russian Jews bent on crossing into Germany. With the German border closed the Russian Jews would then be forced to settle within Israel proper. Germany's response was emphatic: "You must be kidding! We are not closing our borders to Jews!"

Germany is witness to Newton's Third Law of Physics: for every action there is an equal and opposite reaction: to fathom Germany's treatment of its Jewish constituency in 2015, just think the exact opposite of what it was in 1935 when Hitler introduced the Nuremberg Laws stripping Jews of German citizenship. Unlike its neighbor Austria, Germany accepts full responsibility for the horrors of its past. One cannot walk a kilometre in the center of Berlin without bumping into a stark reminder of the Nazi past, and of the human potential for inhumanity and barbarism. It is precisely this unyielding readiness to openly confront its past, and its deep-seated regret, that has energized Germany's spirit, and transformed it into a power-house of moral integrity.

Who could have imagined that the German government (specifically the State of BerlinBrandenburg) would underwrite the formation of a school of Jewish theology, to include budget and faculty salaries, at Potsdam university. Arriving at this astonishing summit took many years, to be exact, only 177 years. It was 1836 when the idea for a Jewish divinity school was first broached by the founder of the Reform movement, Rabbi Abraham Geiger. Two years ago in November 2013 Geiger's vision came to pass. Jewish hope and resilience had crossed another finish line.

What awesome irony stands behind the establishment of this School of Jewish Theology. Potsdam University's campus occupies the gardens and palaces built by Frederick the Great in the mid-18th century. The last Prussian monarch to occupy the palace was Kaiser Wilhelm II, the grandson of Queen Victoria. The irony is that Wilhelm was a polite, but serious anti-Semite. What sweet Jewish payback that the refurbishing of a building to house the School of Jewish Theology sits on the palace grounds some 100 meters from the Kaiser's palace. 
I touch on four illustrations of Jewish renewal. The first, is Limmud Germany, modeled after Limmud England. Limmud's aim is to attract Jews of all persuasions who are interested in Jewish learning within an informal retreat setting. The Limmud model has spread to nearly 70 communities, in 34 countries, on six continents, including here in Toronto. Several weeks ago Limmud Germany attracted 400 participants to a vacation setting at the North Sea.

A second surprising illustration of renewal is that more than half of the members of the Masorti synagogue in Berlin are Jews-by-choice. A third image is a revolutionary project launched by Rabbi Gesa Ederberg, a native German woman and graduate of the Masorti Schechter rabbinical seminary in Jerusalem. She has launched an interfaith pre-school program, still in the planning stages, for children ages 1-5 representing Jewish, Christian, and Muslim children. The aim: within the same building to allow each religion to teach its doctrines and beliefs in separate classes, and at the same time, to build opportunities for the youngsters to mingle together socially, in art classes, in the playground; and in this way to learn first-hand about respect for one another's religious and cultural differences.

A final illustration of hope and renewal relates to my student, Rachel, who converted to Judaism two years ago. As a child of Protestant ministers she was drawn to the morality tales of the Bible. Rachel was emotionally close with her grandmother who was in her late teens when WWII broke out. Years later when Rachel learned about the Shoah in school she approached her grandmother, wondering about the role Germans played in the war who were her grandmother's contemporaries.

Rachel learned that while her grandmother's family hated Hitler, they were silent bystanders. Rachel's grandmother felt tremendous guilt at not having done more to help save Jews. At this juncture, her grandmother encouraged her to read more about the Shoah, and, especially, to read the works of contemporary Israeli authors.

As a teen Rachel became involved with a Jewish organization that sent her to Prague for a year to assist German-speaking survivors of the Shoah. Meeting daily with a group of survivors, she became their 'granddaughter.' Rachel speaks of the irony that in a very small way she was 
repairing a tiny piece of the damage perpetrated by her grandmother's generation. Rachel and her brother are the only ones of twenty-three grandchildren who have become engaged in the act of tikkun, of repair.

Today, Rachel is completing her M.A. in Jewish studies at Potsdam, having spent a semester at Hebrew University where she completed five of six levels of Hebrew language proficiency. We converse in Hebrew. The lesson I continue to learn daily living and teaching in Berlin, is that hope and resilience, as defining qualities of the Jewish spirit, have taken root among a cadre of Berlin's Jewish community. 